\title{
Economic security in the management system of environmental sustainability of investment processes
}

\author{
Alexey Popov* \\ Ural State University of Economics, 8 Marta Str., 62, 620144 Ekaterinburg, Russia
}

\begin{abstract}
The article is devoted to current issues of economic security of economic entities in strengthening environmental sustainability in the implementation of investment activities. The generalized experience of global and local ecological problems demands careful planning and introduction of ecological actions which are formed at a design stage. The author discusses the basic contents of the section "Environment protection" of the design documentation allowing to level threats to ecological safety during construction and operation of an object of investments. The author reviews methods to assess the environmental and economic efficiency of investment projects, the main complexity of which is the allocation of the influx of funds as a result of increased environmental responsibility of business entities. The author justifies the inclusion of the environmental goodwill indicator in the balanced scorecard used to comprehensively assess the activities of enterprises, which will more fully disclose information about the company environmental policy, having a direct impact on financial performance, the improvement of which will ensure economic security and sustainable development.
\end{abstract}

\section{Introduction}

In modern economic conditions, characterized by market saturation, increased competition, unstable energy prices, the negative impact of political factors on international economic relations, the issues of maintaining economic security and ensuring sustainable development of enterprises become of paramount importance. In order to maintain market positions, increase efficiency and ensure financial stability, business entities must offer innovative products and use innovative production and management technologies. At the same time the achievement of these goals is unthinkable without investing in high-tech production, as well as creative development of various types of products and the creation of cyber-systems. At the same time one of the competitive advantages of innovative products is environmental friendliness of their production, as well as safety of their use for the environment. As M.A. Utkova states: "ecological activity also begins to acquire the properties not only of the goods, but also significant capital, as it multiplies the whole system of creating additional opportunities for the development of environmental and economic security"[1] The

\footnotetext{
${ }^{*}$ Corresponding author: prepodpopov@yandex.ru
} 
companies voluntarily taking environmental responsibility provide positive dynamics of financial indicators, because, according to some experts, "environmental responsibility became an obligatory condition of survival in the changing business environment"[1]. Foreign authors began to pay close attention to the issues of companies' environmental responsibility and environmental sustainability management in the last century, as evidenced by the works of Lee J., Richardson D.G.[2], R.L. Rabin[3], Graham A.[4] and others. Russian researchers, in particular O.V. Menshikova[5], O.I. Gorbunova[6], M.N. Saldaeva[7], N.V. Pakhomova[8], R.O. Voskarian[9] and others addressed the above problems somewhat later, publishing a number of scientific works, the main emphasis in which is placed on revealing the main elements of business environmental policy in order to minimize environmental damage. A relatively new direction in the domestic science was the justification of the direct relationship between environmental responsibility and economic security, which is discussed in the works of Y.A. Mazhaisky[10], I.O. Kirilchuk[11], A.F. Mudretsov[12], A.F. Rogachev[13] and others. Ivantsova E.A. gives the following definition of environmental and economic security - "a combination of economic, social and environmental conditions and factors that ensure sustainable and effective development of society, aimed at improving the quality of life of people and the environment."[14] The main attention in the above works is paid to ensuring environmental and economic security in the implementation of production activities, but the issues of environmental and safety at the stage of investment in the economy of the country. The main emphasis in assessing the effectiveness of investment processes is made on the economic component, i.e. payback, which is confirmed by the works of Mirzabekova M.Y.[15], Lavrukhina N.V.[16], Kirillov Y.V.[17]. Malinin S.E.[18] and others. However, due to the growth of global environmental problems and the need to ensure environmental safety, environmental protection issues should be paid close attention at the stage of investment, since the implemented investment projects in the field of industry and construction will have a direct impact on the quality of functioning of society, industries, regions and states in the future. Accordingly, this work aims to address the issues of economic security in the system of environmental sustainability management at the stage of investment processes in the course of investment activities by business entities.

\section{Materials and Methods}

This study was conducted based on the current regulatory framework and a large volume of scientific and practical literature. General scientific and special methods were used to achieve the goal of this study. In particular, on the basis of the method of description and grouping the author carried out the generalization of environmental problems faced by business entities in the course of investment activity. The normative substantiation and basic rules of ensuring environmental friendliness of investment projects implemented by business entities were formulated with the use of methods of observation and deduction. Analytical methods, methods of grouping and comparison were used in parsing models for assessing the environmental and economic efficiency of an investment project. Recommendations on strengthening environmental and economic security and sustainable development of economic entities in the implementation of investment activities were formulated with the use of abstraction and extrapolation.

\section{Results and Discussion}

The negative influence of industrial activity of economic entities of the real sector of economy on the environment during the last century has an inevitable tendency to grow. Professor I.V. Kosyakova notes that "anthropogenic load is approaching its objective limit, 
the unresolved environmental problems become a limitation of the development of many industries"[19]. That is why one of the main trends of sustainable development and environmental sustainability is the elimination of the consequences and leveling of global and local environmental problems. V. A. Grachev, Professor, President of the Russian Ecological Academy, includes "climate change, degradation of the biosphere and water imbalance" in the first group, and "air, water source, soil pollution, waste disposal" in the second group.[20] A. A. Panfilov, Chairman of the Russian Ecological Party "The Greens" complements the list of these problems, including deforestation, radioactive pollution, destruction of protected areas and poaching, etc. The result of the symbiosis of these environmental problems is the growth of diseases caused by pollution and environmental degradation, climate instability, in particular permafrost retreat, floods, storms, hurricanes and other natural disasters, leading to the destruction of infrastructure, damage and loss of human life. The consequence of all these factors is the deterioration of the conditions and quality of life of the population. [20]

Accordingly, in order to level the threats to the environment in the process of implementing investment activities, special attention should be paid to ensuring environmental safety. As you know, construction, reconstruction and modernization of industrial, economic and other facilities, including linear objects (pipelines, power transmission lines, highways, etc.), recognized as structural components of investment activities, are carried out on the basis of the developed design and estimate documentation. The composition of the sections of the design documentation and the requirements for their content are determined by the Decree of the Government of the Russian Federation No. 87 dated February 16, 2008. According to it, the project must include the section "List of measures for environmental protection" (EP section), which, along with the list of actual measures to prevent and reduce the possible negative impact of the planned economic activity on the environment for the period of construction and operation of the capital construction contains a list and calculation of costs for the implementation of environmental protection measures and compensation payments, as well as the results of an environmental impact assessment. The main content of the EP section and its structural components are shown in Fig. 1. 


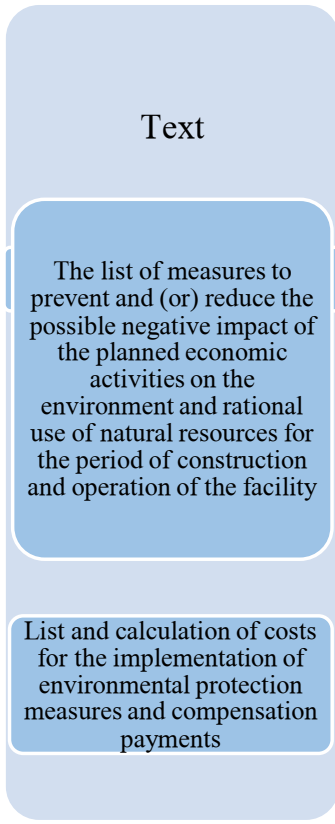

\section{Table}

Situational plan (sketch map) of the building area indicating on it the boundaries of the land plot provided for the placement of the cthe capital construction facility, boundaries of the sanitary protection zone, residential area, recreational zones, water protection zones, protection zones of drinking water supply sources, habitats of animals and plants listed in the Red Book of the Russian Federation and the red books of the constituent entities of the Russian Federation, as well as the locations of calculated points.

Situational plan (sketch map) of the construction area, indicating the boundaries of the land plot provided for the location of the capital construction facility, the location of sources of emissions into the atmosphere of pollutants and devices for cleaning these emissions

Sketch maps and summary tables with the results of calculations of atmospheric pollution under adverse weather conditions and emissions by substances and combinations of substances with cumulative harmful effects - for industrial facilities

Situational plan (sketch map) of the district indicating the boundaries of the land plot provided for the placement of the object cap. construction, indicating control points, posts, wells and other facilities providing water sampling from surface water bodies, as well as groundwater - for industrial facilities

Fig. 1. Typical composition of the EP section of the project documentation for the construction of facilities.

Accordingly, the costs incurred in the course of investment activities to ensure environmental safety should be taken into account when assessing the effectiveness of an investment project and assessing its payback. The main methods for evaluating investment projects are methods of discounting cash flows, which include the calculation of net present value (NPV), internal rate of return (IRR), including modified (MIRR), profitability index (PI), discounted payback period (DPP), as well as traditional methods, which include the estimation of the payback period (PP) and accounting rate of return (ARR).

At the same time, with regard to environmental factors when developing a methodology for evaluating the effectiveness of investment projects, a unified approach has not been developed so far. We have analyzed the methods and points of view put forward by domestic researchers in relation to assessing the environmental efficiency of investment projects. The initial data are presented in Table 1 .

Table 1. Review of methods for assessing the environmental efficiency of investment projects.

\begin{tabular}{|l|l|}
\hline \multicolumn{1}{|c|}{ Author and source } & \multicolumn{1}{|c|}{$\begin{array}{c}\text { Brief description of the effectiveness assessment } \\
\text { methodology }\end{array}$} \\
\hline $\begin{array}{l}\text { D.V. Knyazev, Methodological } \\
\text { scheme for assessing the socio- } \\
\text { economic efficiency of investment } \\
\text { and construction projects. Modern }\end{array}$ & $\begin{array}{l}\text { One of the indicators for assessing environmental } \\
\text { efficiency is the Coefficient of change in the level of gas } \\
\text { contamination in terms of carbon monoxide (CO) and } \\
\text { nitrogen oxides (NOx), calculated by the ratio of the level } \\
\text { of gas contamination of the study area in relation to the } \\
\text { l, 444 (2014). }\end{array}$
\end{tabular}


Table 1. Continued

\begin{tabular}{|c|c|}
\hline $\begin{array}{l}\text { E. E. Bicheva, L. N. Sotnikova, } \\
\text { Environmental efficiency of } \\
\text { investment projects in the agro- } \\
\text { industrial complex. Voronezh State } \\
\text { Agrarian University Bulletin, 3, 183- } \\
189(2018) \text {. }\end{array}$ & $\begin{array}{l}\text { reening, i.e. preliminary review of the project proposal } \\
\text { the initial stage, which involves establishing the } \\
\text { ompliance of the project with environmental criteria and } \\
\text { fining the basic requirements for the composition of } \\
\text { formation required for further preparation and } \\
\text { aplementation of the project. [22] }\end{array}$ \\
\hline $\begin{array}{l}\text { R. A. Maisky, Yu. A., Pavlova, } \\
\text { Proskura, Economic efficienc } \\
\text { projects on environmental prote } \\
\text { and environmental prote } \\
\text { measures. USPTU Bulletin. Sci } \\
\text { Education, Economics. S } \\
\text { Economics, } 4 \text { (22) (2017). }\end{array}$ & $\begin{array}{l}\text { The methodology offers the calculation of the following } \\
\text { indicators: } \\
\text { 1. "The effect from the implementation of environmental } \\
\text { protection measures, which is the sum of the increase in } \\
\text { net income from improving production results as a result } \\
\text { of environmental protection measures and the amount of } \\
\text { economic damage from the disruption or loss of a resource } \\
\text { prevented due to these measures. } \\
\text { 2. The coefficient of efficiency of environmental } \\
\text { protection measures, equal to the quotient of dividing the } \\
\text { magnitude of the effect by the one-time costs for the } \\
\text { implementation of environmental measures ". [23] }\end{array}$ \\
\hline $\begin{array}{l}\text { I. P. Nuzhina, Evaluation of the } \\
\text { effectiveness of an investment } \\
\text { project as a tool for environmental } \\
\text { and economic regulation of } \\
\text { investment and construction } \\
\text { activities in the region. Regional } \\
\text { Economics: Theory and Practice, } 6 \\
(2010) \text {. }\end{array}$ & $\begin{array}{l}\text { flow, } \\
\text { ow of } \\
\text { ental } \\
\text { only } \\
\text { o the } \\
\text { nally } \\
\text { ocio- }\end{array}$ \\
\hline $\begin{array}{l}\text { N.M. Zhuravel, Ecological and } \\
\text { Economic Efficiency of the Best } \\
\text { Available Technologies: Significant } \\
\text { Factors and Their Measures (Part 1). } \\
\text { World of Economics and } \\
\text { Management, 13.4 (2013). }\end{array}$ & $\begin{array}{l}\text { green" indicators of the efficiency of } \\
\text { cts: 1) net discounted income; 2) the } \\
\text { capital investments; } 3 \text { ) internal rate of } \\
\text { back period, adjusted for the calculated } \\
\text { mage and damage prevented as a result } \\
\text { onmental technologies. [25] }\end{array}$ \\
\hline
\end{tabular}

In our opinion, the works of N.P. Nuzhina [24] and Zhuravel N.M. [25] are of the greatest scientific interest, since they provide a detailed mechanism for calculating the ecological and economic effect, which is one of the indicators of the economic security of an enterprise, the achievement of which ensures the sustainable development of both the economic entity itself and industries, regions and the state as a whole. At the same time, the calculation of cash flows for calculating the economic effect includes not only direct income and benefits obtained as a result of the implementation of environmental measures, but also an increase in flows from operating activities, additionally obtained as a result of improving the environmental friendliness of products for use by consumers, and in the process of its manufacture. The calculation of outflows by these researchers included not only the planned costs for the implementation of environmental measures, as well as for covering damage, in particular environmental payments, but also conditional, potential values of damage, i.e. possible costs incurred to mitigate adverse environmental consequences, as well as lost profits. Also, the calculations take into account the time value of money factor (discount factor), taking into account the specifics of the application in relation to environmental costs. However, the main problem of the proposed methods is the conventionality of identifying proceeds from the introduction of environmental measures in the structure of cash flows from operating and investment activities. 
At the same time, in our opinion, when analyzing the environmental sustainability of investment projects in order to strengthen economic security, it makes sense to pay attention to another indicator - the environmental reputation of an economic entity as a structural component of business goodwill. According to RAS 14/2007 "Accounting for intangible assets" in force in the Russian Federation at the time of writing this article, goodwill is an asset formed upon the acquisition of an enterprise as a property complex at a price higher than the book value of the assets and liabilities of the acquired enterprise, which will provide additional economic benefits when carrying out business activities. The purchase price of a successful off-the-shelf business, as a rule, exceeds the book value of assets and liabilities due to established business relationships, accumulated customer base and, in particular, implemented by the subject of environmental policy. In international practice, the equivalent of goodwill is goodwill formed in accordance with IFRS 3 Business Combinations, which means future economic benefits arising from assets that cannot be individually identified and separately recognized. However, neither Russian nor international standards provide for a fundamental methodology for separating the environmental component in goodwill.

This circumstance should be attributed to further areas of scientific research, since information on the environmental activities and environmental sustainability of business entities should be available to an unlimited number of users to the same extent that financial reporting is available (in particular, the Russian Federation provides a state information resource for financial reporting). In favor of this circumstance, we can argue that environmental reputation is an asset that generates a positive cash flow due to the greatest attractiveness for the client base, and this asset can be identified, since most modern companies disclose information about environmental activities and implemented activities in their financial statements. However, the valuation rules for this asset currently require appropriate methodologies. But since a balanced scorecard (BSC) can be used to assess the performance of companies, which provides for the inclusion of financial and non-financial indicators in it, environmental reputation must necessarily be included in the number of nonfinancial indicators, since it is a leading indicator, i.e. a factor contributing to the improvement of financial results in the future. Also, environmental reputation meets the criteria for the remaining non-financial indicators of the BSC, since it:

- is developed taking into account the long-term strategy of the business entity;

- timely and truthfully reflects the achieved level of efficiency at any given time;

- reflects one of the key factors for the success of the enterprise.

Its use will expand the range of disclosure of useful information both for business owners and shareholders and for external investors in order to further develop investment activities, strengthen economic security and ensure sustainable development.

\section{Conclusions}

The issues of ensuring economic security in the management system for the environmental sustainability of investment processes considered in this article will allow business entities to develop an effective environmental policy that forms a state of protection from external threats and a trend of continuous development and effective functioning in the future. When planning investments, close attention should be paid to environmental protection by developing a list of measures to level the negative impact on it. At the same time, an increase in the costs of environmental activities at first glance may reduce the current financial indicators and demonstrate a longer payback period for investment projects, but in the future these costs will bring great economic benefits due to the increased environmental responsibility of business entities and the formation of a general environmental awareness. The considered methods for assessing the environmental efficiency of investment projects indicated the need for further research in this area due to the difficulty of identifying eco- 
flows in the structure of total cash flows for operating and investment activities, however, the proposed expansion of the balanced scorecard and the inclusion of data on environmental reputation in it will allow disclosing more complete information about business entities in order to attract new investments and sustainable development of industries, regions and the state as a whole.

\section{References}

1. M.A. Utkova, P. Yu. Utkov, Ecological and economic security in the system of regional management (2014)

2. Y. Li, G. D. Richardson, D. B. Thornton, Contemporary accounting research, 14.3, 435 (1997)

3. R.L. Rabin, 24 Hous. L. Rev, 27, 31 (1987)

4. A. Graham, J.J. Maher, W.D. Northcut, Journal of Accounting, Auditing \& Finance, 16.2, 93 (2001)

5. O.V. Menshikova, V.V. Menshikov, Bulletin of the International Academy of Sciences, 2, 027 (2012)

6. O.I. Gorbunova, L.V. Kanitskaya, Bulletin of the Baikal State University, 27.3 (2017)

7. M.N. SaldaevaBulletin of the Samara State Technical University. Series: Economic Sciences, 3, 9 (2013)

8. N.V. Pakhomova, G.B. Malyshkov, Problems of the Modern Economy, 2, 310 (2008)

9. R.O. Voskanyan, Finance and Credit, 25.6, 1454 (2019)

10. Yu. A. Mazhaisky, V. N. Minat, Rural Development and Social Policy Bulletin, 2 (14) (2017)

11. I.O. Kirilchuk, V.L. Rykunova, Bulletin of the South-West State University, 22.2, 94 (2018)

12. A. F. Mudretsov, National security (ecological and economic aspect): concepts, problems, solutions (2011)

13. A. F. Rogachev, I. V. Isaev, N. N. Skeeter, Bulletin of the Nizhnevolzhsky agrouniversity complex: Science and higher professional education, 4(32) (2013)

14. E. A. Ivantsova, V. A. Kuzmin, Bulletin of the Volgograd State University. Series 3: Economics. Ecology, 5 (2014)

15. M. Yu. Mirzabekova, Innovative Science, 1-1 (13) (2016)

16. N.V. Lavrukhina, Theory and Practice of Social Development, 16 (2014)

17. Yu. V. Kirillov, E. E. Dosuzheva, Economic Analysis: Theory and Practice, 32(335) (2013)

18. S.E. Malinina, Creative Economy, 4(88) (2014)

19. I.V. Kosyakova, Methodological foundations for the formation of a mechanism for the economic provision of environmental safety of industrial activities of industrial enterprises (2007)

20. V.A. Grachev, O.V. Plyamina, Age of Globalization, 1(21) (2017)

21. D.V. Knyazev, Modern problems of science and education, 4, 444 (2014)

22. E.E. Bicheva, L. N. Sotnikova, Voronezh State Agrarian University Bulletin, 3, 183 (2018) 
23. R.A. Maisky, Yu. A., Pavlova, V. S. Proskura, USPTU Bulletin. Science, education, economics. Series: Economics, 4(22) (2017)

24. I.P. Nuzhina, Regional Economics: Theory and Practice, 6 (2010)

25. N.M. Zhuravel, World of Economics and Management, 13.4 (2013) 